\title{
Nuclear Factor Kappa B Activation in Human Cord Blood Mononuclear Cells
}

\author{
CHRISTIAN H. SCHROETER, BIANCA SCHAUB, DIANE R. GOLD, PAOLA J. CONTRERAS, \\ OSCAR MANRIQUE, MATTHEW W. GILLMAN, SCOTT WEISS, LYLE J. PALMER, \\ DAVID PERKINS, AND PATRICIA W. FINN
}

\author{
Pulmonary and Critical Care Division [C.H.S., B.S., P.J.C., O.M., P.W.F.], Channing Laboratory [D.R.G., \\ S.W., L.J.P], Immunogenetics and Transplantation [D.P.], Brigham and Women's Hospital, Harvard \\ Medical School, Boston, Massachusetts, 02115, U.S.A., and Department of Ambulatory Care and \\ Prevention, Harvard Medical School and Harvard Pilgrim Health Care, Boston, Massachusetts, 02115, \\ U.S.A. [M.W.G.]
}

\section{ABSTRACT}

The immunologic signals participating in immune responses early in life have not been completely elucidated. Regarding the characterization of neonatal cells, little is known concerning the activity of transcription factor nuclear factor kappa B (NF- $\kappa$ B), which regulates inflammatory genes and cytokine production. The aim of this study was to characterize NF- $\kappa$ B activation in cord blood mononuclear cells (CBMC). We analyzed the potential association of NF- $\kappa \mathrm{B}$ activity with lymphocyte proliferation and influences on cytokine secretion in the early immune system. To determine the contribution of a disease whereby inheritance may impact neonatal immunity, we assessed the influence of maternal allergic disease on NF- $\kappa \mathrm{B}$ regulation and cytokine secretion. CBMC from healthy newborns were isolated and stimulated with mitogen $(n=28)$. Nuclear extracts were analyzed by electrophoretic mobility shift assay, cytokine secretion by ELISA. FISH analysis excluded relevant maternal contamination of CBMC. All samples showed a positive lymphoproliferative response, and NF- $\kappa \mathrm{B}$ activity was both increased and decreased after mitogen stimulation. Increased NF- $\kappa \mathrm{B}$ activation was significantly associated with decreased TNF- $\alpha$ secretion (median 6.1 versus $50.3 \mathrm{pg} / \mathrm{mL}$ ) in unstimulated CBMC. Mitogen stimulation resulted in increased NF- $\kappa \mathrm{B}$ activity with a trend to increased IL-13 production. Maternal allergic disease was associated with higher TNF- $\alpha$ (median 982 versus $173 \mathrm{pg} / \mathrm{mL}$ ) and IL-13 secretion (median 1328 versus $1120 \mathrm{pg} / \mathrm{mL}$ ) after mitogen stimulation. Together, NF- $\kappa \mathrm{B}$ activity is differentially activated in cord blood and associated with a distinct cytokine pattern. Whether differential NF- $\kappa \mathrm{B}$ activity in cord blood is related to the subsequent development of immune diseases requires further investigation. (Pediatr Res 56: 212-218, 2004)

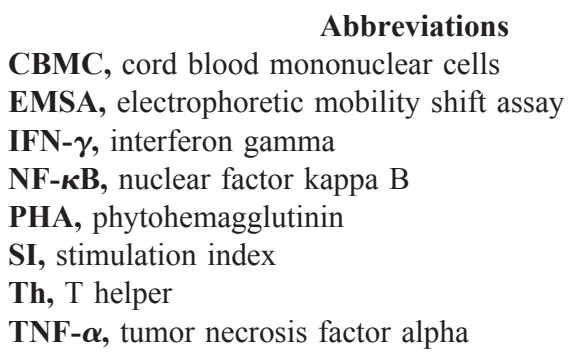

Neonatal immune responses have been postulated to be less mature than adult immune responses, however, the mechanisms involved in these responses are not well characterized. Data regarding regulatory mediators such as transcription factors are limited for the neonatal immune system. A likely candidate for regulation of early immune responses is the ubiquitous transcription factor NF- $\kappa \mathrm{B}$, which plays a critical

Received September 22, 2003; accepted March 25, 2004.

Correspondence: Patricia W. Finn, M.D., Pulmonary and Critical Care Division, Brigham and Women's Hospital, 75 Francis St., Boston, MA 02115, U.S.A.; e-mail: pwfinn@rics.bwh.harvard.edu

Supported by grant 5R01AI045007-04, HD 34568, HL 64925, HL 68041, HL 61907, DFG 711/1-1.

C.H.S. and B.S. contributed equally to the work.

DOI: 10.1203/01.PDR.0000132850.33375.D0 role in the regulation of many inflammatory genes, such as those encoding inflammatory cytokines, regulatory chemokines, adhesion receptors, enzymes, and inducible nitric oxide synthase (1-8). The NF- $\kappa$ B proteins belong to the Rel family of proteins, which include five family members: RelA (p65), RelB, c-Rel, NF- $\kappa$ B1 (p50), and NF- $\kappa$ B2 (p52) (9-11).

Transcription factor activity may be influential in the development of immune-mediated disorders, which are established at an early time point in life. Analysis of CBMC offers a unique opportunity to examine transcription factor activity before the development of immune-mediated diseases. To date, the neonatal immune phenotype has been characterized by the type of cytokines secreted, but these cytokines have not been extensively examined in relationship to transcription factor activation. Cord blood is presumed to express a Th2 (e.g. IL-13, 
IL-5) predominant cytokine pattern $(12,13)$. The transcription factor GATA3 promotes Th2 cell differentiation and is implicated to be controlled by NF- $\kappa \mathrm{B}$ activity $(6,14,15)$. In contrast, the transcription factor STAT4 promotes Th1 cell differentiation (6). Little is known about NF- $\kappa \mathrm{B}$ activity in relation to cytokine secretion in the early immune system, which may be a candidate for regulation of distinct pathways.

Another critical consideration in the development of immune-mediated disorders is that maternal diseases and environmental exposure may also influence the neonatal immune system. Recent studies found a reduced Th1 cytokine (IFN- $\gamma$ ) secretion from CBMC with a parental history of allergic diseases $(16,17)$. CBMC proliferate to mitogens $(17-23)$, and mitogen or allergen-induced cytokine production is presumed to be Th2 predominant (24).

In our characterization of neonatal immune responses, we investigated potential links between NF- $\kappa \mathrm{B}$ activity and functional capacity of human CBMC by analysis of lymphocyte proliferation and cytokine secretion before and after stimulation with the mitogen PHA. As maternal history of allergic diseases potentially influences neonatal cytokine secretion, maternal allergic disease was included in our analysis.

\section{METHODS}

Study population. The study population was a subset of participants in Project Viva, a pregnancy and birth cohort study underway in the Boston metropolitan area in the United States. The consent of expectant mothers was obtained at their initial prenatal visit. Participants were interviewed and completed questionnaires in the first and second trimesters of pregnancy, as well as at the time of delivery. The following variables were assessed: maternal history of doctor diagnosis of asthma, hay fever and/or eczema, reproductive and other medical history, and lifestyle factors, including smoking. From medical records, we evaluated labor and delivery variables. At the time of delivery, we collected venous umbilical cord blood from Viva newborns. Clinical data were retrospectively evaluated after laboratory data were obtained. Informed consent was obtained from mothers for their participation, including cord blood collection and $3 \mathrm{y}$ of follow-up of their offspring. This study was approved by the Human Subjects Review Committees of Harvard Pilgrim Health Care and the Brigham and Women's Hospital, Boston.

Cord blood samples, cell preparation, and lymphocyte proliferation. Cord blood samples $(n=28)$ were collected by withdrawing blood from the umbilical vein after delivery. Samples were placed in heparinized tubes and processed within $24 \mathrm{~h}$. CBMC were isolated by density-gradient centrifugation with Ficoll-Hypaque Plus (Pharmacia, Uppsala, Sweden) after dilution in PBS. Cells were washed in RPMI 1640 (Cellgro, Mediatech, Herndon, VA, U.S.A.) and diluted in 10\% human serum (BioWhittaker, Walkersville, MD, U.S.A.). For lymphocyte proliferation assay, $\mathrm{CBMC}$ were cultured in quadruplicate in 96-well tissue-culture plates (Corning, Palo Alto, CA, U.S.A.) for $3 \mathrm{~d}$ and pulsed with $1 \mu \mathrm{Ci}{ }^{3} \mathrm{H}$-thymidine for an additional $8 \mathrm{~h}$. Cell cultures were performed at $37^{\circ} \mathrm{C}$ in a humidified $5 \% \mathrm{CO}_{2}$ incubation chamber. Cells were harvested with a Tomcat Mach II harvester (Wallac, Turku, Finland) onto filter plates, which were read using a $\beta$-counter. Proliferation was quantified by SI, which is calculated as the ratio of mean counts per minute (cpm) of stimulated over unstimulated replicates. A positive SI was defined by SI $>3$.

Cytokine measurements. Supernatants from cell cultures were harvested after $24 \mathrm{~h}$ of incubation in media and after 24 and $60 \mathrm{~h}$ of stimulation with PHA $(5 \mu \mathrm{g} / \mathrm{mL}$, Sigma Chemical, St. Louis, MO, U.S.A.) $(n=28)$. Commercially available human ELISA kits (Endogen Corporation, Woburn, MA, U.S.A.) for IFN- $\gamma$, TNF- $\alpha$, IL-13, IL-5, and IL-10 were used according to the manufacturer's instructions. Detection limits were $2.0 \mathrm{pg} / \mathrm{mL}$ for IFN- $\gamma$ secretion, $2.0 \mathrm{pg} / \mathrm{mL}$ for TNF- $\alpha, 7.0$ $\mathrm{pg} / \mathrm{mL}$ for IL-13, $2.0 \mathrm{pg} / \mathrm{mL}$ for IL-5, and $3.0 \mathrm{pg} / \mathrm{mL}$ for IL-10 secretion.

Nuclear extract preparation and electrophoretic mobility shift assay. Nuclear extracts were prepared after $1 \mathrm{~h}$ of incubation in media or in the presence of PHA $(5 \mu \mathrm{g} / \mathrm{mL})$ as previously described (25-27). Briefly, cells were washed with PBS, pelleted, and resuspended in $400 \mu \mathrm{L}$ of buffer A. After incubation for $15 \mathrm{~min}$ on ice, they were spun for $30 \mathrm{~s}$ and resuspended in buffer $\mathrm{C}$. After incubation on a shaking platform for $15 \mathrm{~min}$ at $4^{\circ} \mathrm{C}$, they were spun for $10 \mathrm{~min}$. Supernatant was collected and stored at $-80^{\circ} \mathrm{C}$ until analysis of nuclear extracts. EMSA was performed as previously described (26). Briefly, nuclear extracts were incubated with radio-labeled consensus sequence for either NF- $\kappa \mathrm{B}$ (5'-AGT TGA GGG GAC TTT CCC AGG C-3'; Promega, Madison, WI, U.S.A.), STAT4 (5'-GAG CCT GAT TTC CCC GAA ATG ATG AGC TAG-3', Santa Cruz Biotechnology, Santa Cruz, CA, U.S.A.), or GATA3 (5'-CAC TTG ATA ACA GAA AGT GAT AAC TCT-3', Santa Cruz Biotechnology) and separated on a 5\% polyacrylamide gel. For supershift experiments, nuclear extracts were preincubated with polyclonal antibodies against p65, p50, and c-rel (Geneka, Montreal, Canada), or MAb against STAT4 and GATA3 (Santa Cruz Biotechnology). Competition assay was performed with STAT4 with unlabeled oligonucleotides. Supershifts for STAT4 were compared with the control cell line Jurkat (Geneka) in each experiment. Supershifts for GATA3 were compared with the control cell line CCRF-CEM (Geneka). For competition experiments, nuclear extracts were preincubated with the unlabeled consensus sequence in 50-fold excess. Dried gels were analyzed by the PhosphorImager system and ImageQuant software (Amersham Biosciences, Uppsala, Sweden).

Detection of maternal cells within CBMC samples. After isolation, CBMC were incubated with Colcemid (Invitrogen) for $30 \mathrm{~min}$, pelleted, resuspended in $0.54 \% \mathrm{KCl}$, and incubated at $37^{\circ} \mathrm{C}$ for $25 \mathrm{~min}$. Cells were fixed with $33 \%$ glacial acetic acid in methanol and spotted onto glass slides. $\mathrm{X}$ and $\mathrm{Y}$ chromosomes were stained using an $\mathrm{X}$ and $\mathrm{Y} \alpha$-satellite twocolor direct labeling kit (Rainbow Scientific, Banbury, UK). Maternal cells were identified by nuclei with XX versus fetal cells by nuclei with XY karyotype. We randomly selected 10 of the 14 male samples for karyotyping.

Statistical analysis. Cytokine levels were not normally distributed and could not be transformed to normality. Nondetectable concentrations were assigned a value of 0.01 for inclusion 
into the analysis. Nonparametric tests (Kruskal-Wallis, MannWhitney) were used to compare median cytokine levels between different groups. Chi-square tests were used to compare categorical variables. Statistical significance was defined as $p$ $<0.05$.

\section{RESULTS}

Study population. Neonatal and maternal data were available on 28 subjects whose cord blood was sampled (Table 1). Gender distribution of neonates was equal.

Detection of maternal cells within CBMC samples. A potential bias of contamination of CBMC with maternal cells was assessed by karyotyping male newborns. CBMC from male newborns $(n=10)$ were analyzed for a female karyotype by staining $\mathrm{X}$ and $\mathrm{Y} \alpha$-satellites with different fluorescent colors and counting 1000 nuclei per sample. Seven subjects revealed female cells with a maximum of $8 / 1000$ cells in one sample (data not shown). Thus, in these samples used for immunologic analysis, relevant contamination by maternal cells was excluded.

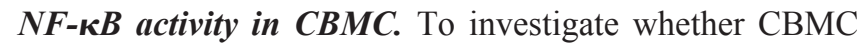
have specific activity of different transcription factors, we analyzed NF- $\kappa$ B, STAT4, and GATA3 DNA binding after stimulation with the mitogen PHA. We chose the mitogen PHA as T-cell stimulant to assess NF- $\kappa \mathrm{B}$ activation in relation to lymphocyte proliferation and cytokine secretion. Kinetic response curves assessing stimulation with PHA for 20, 40, 60, and $120 \mathrm{~min}$ in CBMC revealed the highest activation at 60 min (Fig. 1A). Based on those results, we analyzed NF-kB activation after stimulation with PHA for $1 \mathrm{~h}$. NF- $\kappa \mathrm{B}$ was detected in all tested samples $(n=28)$ (Fig. 1, B and $C$ ). Supershift assays were performed in a subset of samples to identify NF- $\kappa \mathrm{B}$ specific subunits (e.g., p65, p50, and c-rel). In all 28 samples, the inducible NF- $\kappa \mathrm{B}$ complexes were supershifted with antibodies against p65 (Fig. 1, $B$ and $C$, shows two representative samples) and p50 (8 of 15 samples, data not shown) indicating the contribution of p65 in the shift complexes. The NF- $\kappa \mathrm{B}$ subunit c-rel was not detectable in these samples (data not shown). In parallel analyses, nuclear extracts were tested against STAT4 and GATA3 oligonucleotides. STAT4 binding was observed (19 of 26 samples), as determined by supershift and competition analysis. GATA 3 binding was observed (14 of 27 samples), as detected by competition analysis (data not shown). As NF- $\kappa \mathrm{B}$ activity was

Table 1. Characteristics of the study population

$\begin{array}{lc}\text { Neonatal data }(n=28) & \\ \text { Gestational age (wk in mean } \pm \text { SD) } & 39.6( \pm 2.1) \\ \text { Gender (male) \% (no.) } & 50 \quad(14) \\ \text { Birth length (cm } \pm \text { SD) } & 50.8( \pm 3.0) \\ \text { Birth weight }(\mathrm{g} \pm \mathrm{SD}) & 3488 \quad( \pm 645) \\ \text { Vaginal delivery \% (no.) } & 71(20) \\ \text { Maternal data }(n=28) & 30.0( \pm 4.7) \\ \text { Age at delivery (y in mean } \pm \mathrm{SD}) & 32(9) \\ \text { History* of allergic diseases: asthma, } & \end{array}$

\footnotetext{
* By questionnaire: "Has a health professional ever told you that you have asthma, hay fever, or eczema?"
}
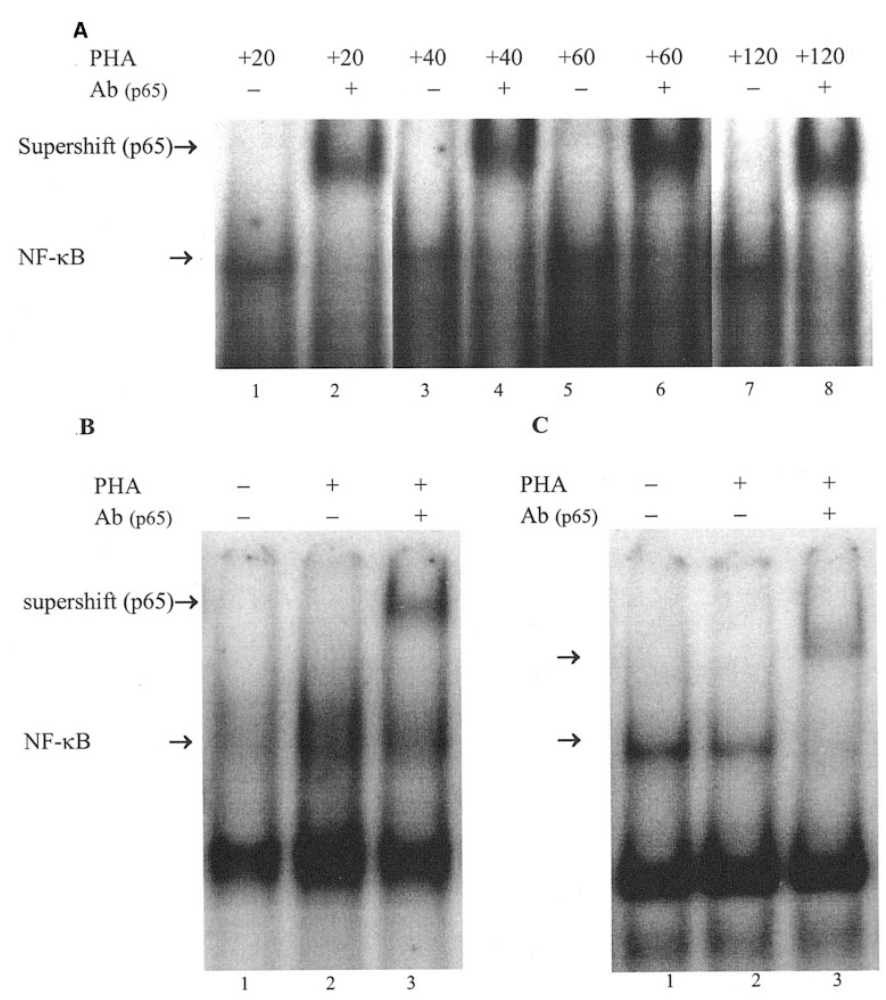

Figure 1. Specific DNA binding activities of NF- $\kappa \mathrm{B}$ in human CBMC. $(A)$ Kinetic analysis of NF- $\kappa$ B activation after stimulation with PHA for 20, 40, 60, and $120 \mathrm{~min}$ in CBMC (indicated as $+20,+40,+60,+120$ ). Nuclear extracts from PHA-stimulated CBMC (lanes 1-8) were incubated with radio-labeled $\mathrm{NF}-\kappa \mathrm{B}$. NF- $\kappa \mathrm{B}-$-specific bands were confirmed by supershift experiments using polyclonal antibodies against p65 (lanes 2, 4, 6, 8). One representative cord blood sample is shown. ( $B$ and $C$ ) Example of a neonate with increased NF- $\kappa \mathrm{B}$ DNA binding $(A)$ and a neonate with decreased NF- $\kappa \mathrm{B}$ DNA binding $(B)$. Nuclear extracts from unstimulated (lane 1) and PHA-stimulated CBMC (lane 2) were incubated with radio-labeled NF- $\kappa$ B. NF- $\kappa$ B specific bands were confirmed by supershift experiments using polyclonal antibodies against $\mathrm{p} 65$ (lane 3). (A-C) Nuclear protein extracts were prepared from CBMC unstimulated (lane 1 in $B, C$ ) or stimulated with PHA (lanes 2 and 3 in $B, C$ ) as described in "Methods." Nuclear extracts were incubated with radio-labeled consensus sequences for NF- $\kappa \mathrm{B}$ and analyzed by EMSA. Bottom arrow indicates NF- $\kappa \mathrm{B}$ DNA binding. Top arrow indicates supershift with $\mathrm{p} 65$ antibody. Density of bands was analyzed by ImageQuant software and a ratio of density from stimulated over unstimulated nuclear extracts was created as described in "Methods"; $n=28$ total subjects.

prominent in all samples, we focused primarily on NF- $\kappa \mathrm{B}$ activity for further analysis.

Differential $N \boldsymbol{F}-\boldsymbol{\kappa} \boldsymbol{B}$ regulation. To quantify NF- $\kappa \mathrm{B}$ DNA binding, specific NF- $\kappa$ B bands were measured by densitometry and a ratio of the density from stimulated compared with unstimulated extracts was calculated. After densitometry analysis, the number 1 was selected to indicate "no change" in $\mathrm{NF}-\kappa \mathrm{B}$ regulation (stimulated above unstimulated not different). In multiple repetitions of NF- $\kappa \mathrm{B}$ EMSA assays in the identical CBMC sample $(n=3)$, we selected $15 \%$ as the range of "no change." Therefore, $15 \%$ above (1.15) and below 1 (0.87) was selected as the range of no change. Due to logarithmic transformation, the value above 1 is 1.15 and the value below 1 is 0.87 and the range "no change" was set between 0.87 and 1.15 . The group with no change in NF- $\kappa \mathrm{B}$ activation was not used for further statistical analysis (Fig. 2, $n=2$ ). 


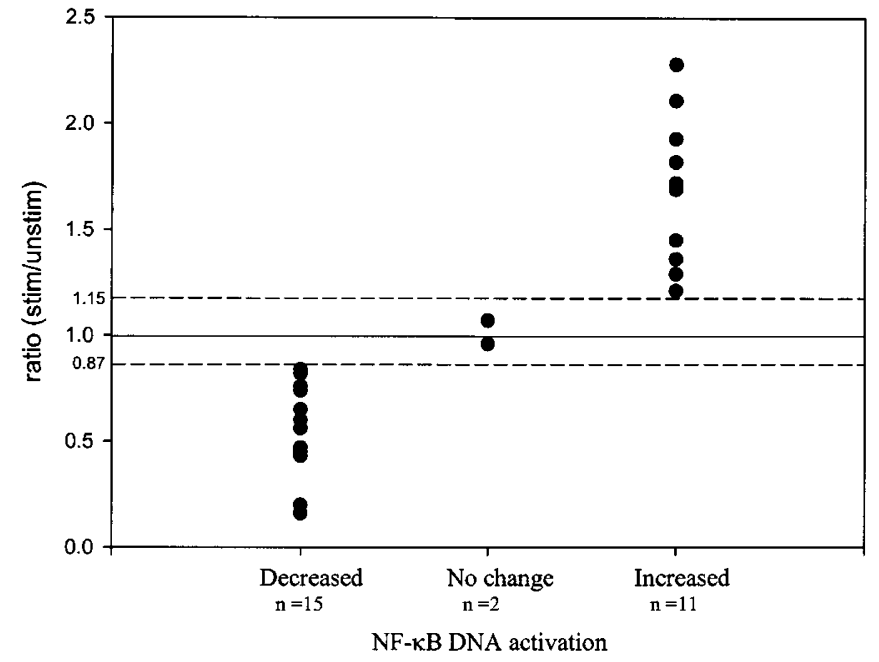

Figure 2. Differential NF- $\kappa$ B DNA binding after PHA stimulation of CBMC. $\mathrm{NF}-\kappa \mathrm{B}-\mathrm{DNA}$ binding was measured by densitometry. The ratio of the density of stimulated over unstimulated nuclear extracts was calculated as described in "Methods." Three groups were created: decreased for a ratio below $0.87(n=$ $15)$, no change for a ratio $\geq 0.87$ and $\leq 1.15(n=2)$, and increased for a ratio above $1.15(n=11)$.

Eleven subjects showed "increased" (ratio above 1.15) and 15 subjects showed "decreased" NF- $\kappa \mathrm{B}$ activation (ratio below 0.87 ) (Fig. 2). The "decrease" in NF- $\kappa$ B activation was not due to higher baseline levels in NF- $\kappa \mathrm{B}$ activation, as additional analysis indicated the ratio is independent of NF- $\kappa \mathrm{B}$ baseline levels (data not shown). Together, these data indicate that specific NF- $\kappa$ B DNA-binding (increased or decreased) can be detected in CBMC.

Positive lymphoproliferative response regardless of differential $\boldsymbol{N F}-\boldsymbol{\kappa} \boldsymbol{B}$ activity. CBMC were stimulated with the mitogen PHA to induce maximal activation in neonatal cells. A positive lymphoproliferative response to PHA stimulation (SI $>3$ ) was detected in all subjects and did not differ with increased or decreased NF- $\kappa$ B activation (Fig. 3).

Increased $\mathrm{NF}-\kappa \mathrm{B}$ activation is associated with decreased TNF- $\alpha$ production in unstimulated CBMC. To further characterize NF- $\kappa$ B activity in CBMC in correlation with other immune parameters, samples with increased versus decreased $\mathrm{NF}-\kappa \mathrm{B}$ activation were analyzed for cytokine secretion. Following initial dose-response-curves (data not shown), cytokine secretion was determined at baseline and after 24 and $60 \mathrm{~h}$ of stimulation with the mitogen PHA. We chose TNF- $\alpha$ and IFN- $\gamma$ as pro-inflammatory and Th1 cytokines, respectively, and IL-13, IL-5, and IL-10 as Th2 cytokines. We observed lower levels of TNF- $\alpha$ in unstimulated CBMC when NF- $\kappa$ B activation was increased compared with decreased NF- $\kappa \mathrm{B}$ activation (median 6.1 versus $50.3 \mathrm{pg} / \mathrm{mL}$, Fig. $4 A$, inset). NF- $\kappa \mathrm{B}$ activation was not associated with TNF- $\alpha$ secretion in CBMC after 24 or $60 \mathrm{~h}$ of PHA stimulation (Fig. 4A).

Increased $N F-\kappa B$ activation is associated with higher IL-13 production in stimulated CBMC. IL-13 secretion at baseline was similar in unstimulated samples with increased or decreased NF- $\kappa$ B activation. After stimulation with PHA, we observed a trend to higher IL-13 secretion in CBMC with increased NF- $\kappa \mathrm{B}$ activation compared with decreased NF- $\kappa \mathrm{B}$

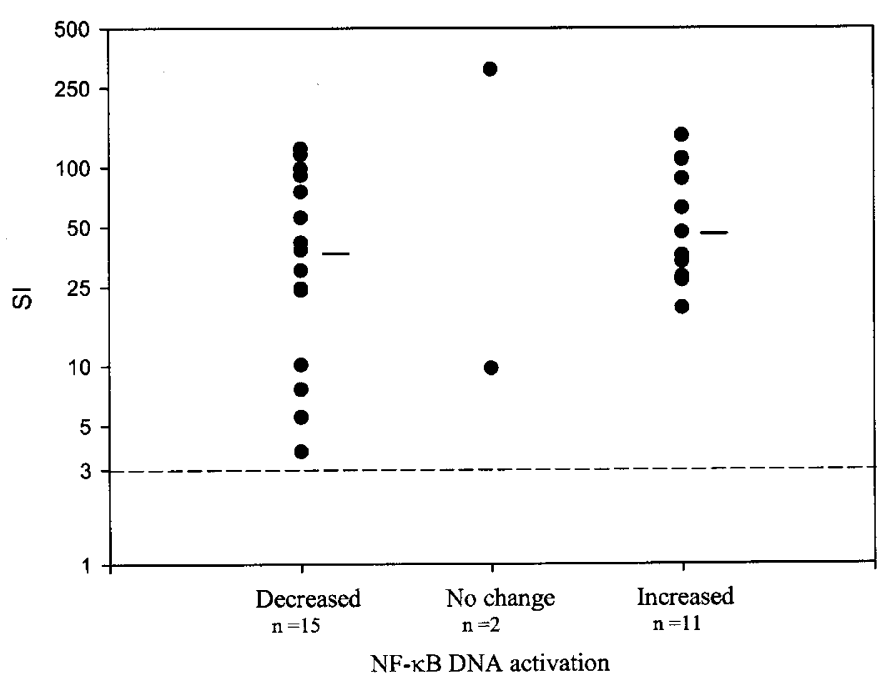

Figure 3. Variation of lymphocyte proliferation independent of NF- $\kappa$ B activation. Lymphocyte proliferation was similar in CBMC with increased compared with decreased NF- $\kappa$ B activity. Lymphocyte proliferation was determined in the presence or absence of PHA stimulation for $3 \mathrm{~d}$ by ${ }^{3} \mathrm{H}$ thymidine uptake as described in "Methods." A ratio of counts per minute from stimulated over unstimulated cells was created. A positive lymphoproliferative response to PHA was defined as a SI $>3$. Horizontal lines represent the median.

activation (median 478.9 versus $107.9 \mathrm{pg} / \mathrm{mL}$ after $24 \mathrm{~h}$; median 1255.7 versus $1119.9 \mathrm{pg} / \mathrm{mL}$ after 60 h) (Fig. $4 B$ ). Similarly, subjects in the highest quartile of IL-13 secretion $60 \mathrm{~h}$ after stimulation showed an increase in NF- $\kappa \mathrm{B}$ activation compared with those in the lowest quartile of IL-13 secretion (data not shown). NF- $\kappa$ B activation was not related to cytokine secretion of IL-5, IL-10, or IFN- $\gamma$ (data not shown). Neither $\mathrm{NF}-\kappa \mathrm{B}$ activation nor cytokine levels were associated with maternal age, delivery type, gestational age, gender, or birth weight as potential confounders.

Stimulated CBMC with maternal history of allergic disease showed no association with $N F-\kappa B$ regulation, but had higher TNF- $\alpha$ and IL-13 secretion. We investigated a potential association between maternal history of allergic diseases and NF- $\kappa \mathrm{B}$ activation. The NF- $\kappa \mathrm{B}$ ratio of CBMC with maternal history of allergy was not different from the ratio of CBMC without maternal history of allergy (median 0.84 versus $0.82, p=0.36$, data not shown).

CBMC of neonates with a positive maternal history of allergic disease produced significantly higher TNF- $\alpha$ and IL-13 secretion after PHA stimulation, whereas the secretion in unstimulated CBMC was similar (Table 2). Maternal history of allergic disease was also associated with higher IL-5 levels after $60 \mathrm{~h}$ of PHA stimulation and lower IL-10 secretion in unstimulated $\mathrm{CBMC}$, though not significant. Maternal history of allergic disease was unrelated to IFN- $\gamma$ secretion.

\section{DISCUSSION}

Neonatal immune responses are classically characterized as immature, but emerging literature suggests that the early immune system may be further developed than previously thought $(13,28-30)$. In this study, we focused on the transcription factor $N F-\kappa B$, which plays a crucial role in gene 


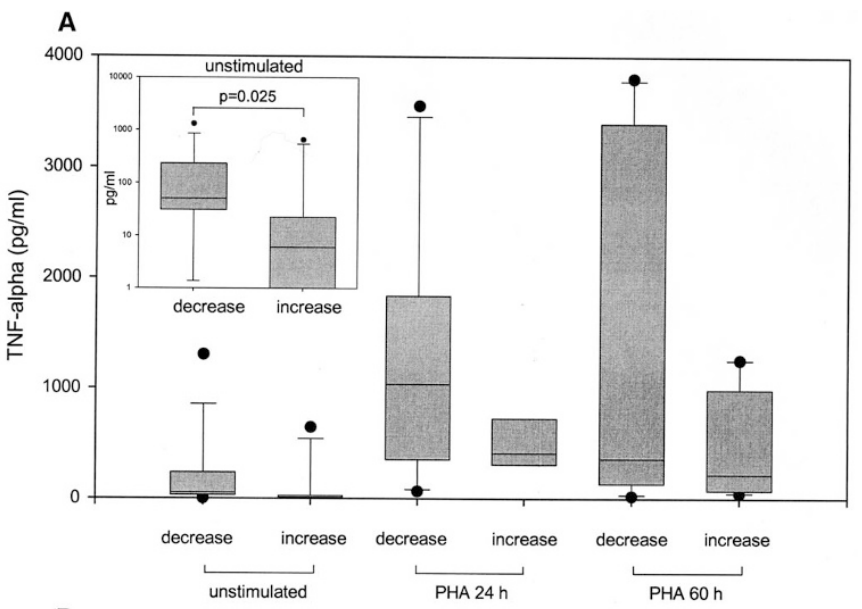

B

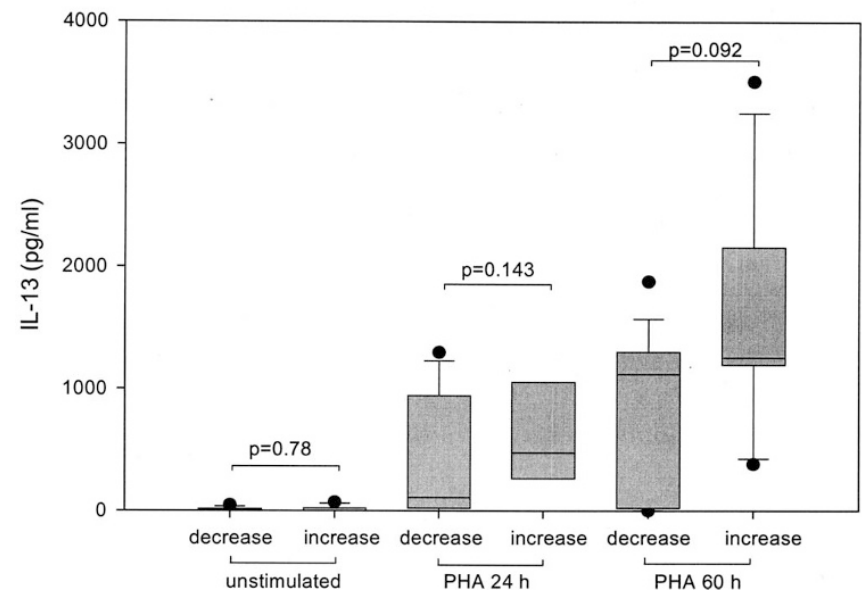

Figure 4. Increased NF- $\kappa \mathrm{B}$ activation is associated with decreased TNF- $\alpha$ secretion at baseline and increased IL-13 secretion after PHA stimulation. Significantly lower TNF- $\alpha$ secretion was detected in CBMC with increased NF- $\kappa \mathrm{B}$ activation in unstimulated samples $(A$, inset) Inset in $A$ indicates cytokine secretion of TNF- $\alpha$ in unstimulated cells with logarithmic scaled $y$ axis for TNF- $\alpha$ levels. A trend of increased IL-13 secretion in CBMC was observed for increased NF- $\kappa$ B activation after $60 \mathrm{~h}$ of PHA stimulation $(B)$. Cytokine secretion of TNF- $\alpha$ and IL-13 in mitogen-stimulated CBMC was compared with secretion in unstimulated samples. Data are shown as box and whiskers plots (median, whiskers: $5 \%$ and $95 \%$ ) with outliers. Pair-wise comparison between "decrease" and "increase" in NF- $\kappa \mathrm{B}$ production was quartile analyzed for each time point by Mann-Whitney $U$ test.

regulation of many immune-mediated diseases $(1,2,4,31)$. Our results in CBMC indicate that NF- $\kappa \mathrm{B}$ activity is differentially regulated (increased as well as decreased) after mitogen stimulation concomitant with positive lymphocyte proliferation. Further, NF- $\kappa \mathrm{B}$ activation is associated with TNF- $\alpha$ secretion and does not correlate with maternal history of allergic diseases. In this study, relevant maternal contamination in CBMC was excluded.

Few reports exist regarding transcription factors, and in particular NF- $\kappa \mathrm{B}$, in the human neonatal immune system. Prior studies reported inducible NF- $\kappa$ B subunits after TNF- $\alpha$ stimulation and also higher expression in neonatal samples than in adults (32-34). In our study, NF- $\kappa$ B activation (p65 and p50) was detectable in neonatal cord blood. Interestingly, NF- $\kappa \mathrm{B}$ was not only increased, as previously reported $(32,33,35)$, but also decreased after mitogen stimulation. Regardless of NF- $\kappa \mathrm{B}$
Table 2. Relation between maternal allergic disease and neonatal cytokine levels

\begin{tabular}{|c|c|c|c|}
\hline Cytokines & $\begin{array}{c}\text { Maternal history } \\
\text { of allergic } \\
\text { disease } \dagger\end{array}$ & Median & $\begin{array}{c}\text { Kruskal- } \\
\text { Wallis test } \\
(p \text { value })\end{array}$ \\
\hline \multicolumn{4}{|l|}{ IFN- $\gamma$} \\
\hline \multirow[t]{2}{*}{ Unstimulated } & Yes & 0.01 & 0.26 \\
\hline & No & 2.70 & \\
\hline \multirow[t]{2}{*}{ PHA 24 h } & Yes & 13.55 & 0.75 \\
\hline & No & 10.62 & \\
\hline \multirow[t]{2}{*}{ PHA $60 \mathrm{~h}$} & Yes & 22.59 & 0.77 \\
\hline & No & 9.86 & \\
\hline \multicolumn{4}{|l|}{ TNF- $\alpha$} \\
\hline \multirow[t]{2}{*}{ Unstimulated } & Yes & 36.87 & 0.43 \\
\hline & No & 30.83 & \\
\hline \multirow[t]{2}{*}{ PHA $24 \mathrm{~h}$} & Yes & 1392.69 & 0.05 \\
\hline & No & 400.14 & \\
\hline \multirow[t]{2}{*}{ PHA $60 \mathrm{~h}$} & Yes & 982.10 & $0.04 *$ \\
\hline & No & 173.31 & \\
\hline \multicolumn{4}{|l|}{ IL-5 } \\
\hline \multirow[t]{2}{*}{ Unstimulated } & Yes & 0.01 & 0.29 \\
\hline & No & 0.01 & \\
\hline \multirow[t]{2}{*}{ PHA 24 h } & Yes & 0.01 & 0.61 \\
\hline & No & 0.01 & \\
\hline \multirow[t]{2}{*}{ PHA $60 \mathrm{~h}$} & Yes & 36.75 & 0.10 \\
\hline & No & 5.61 & \\
\hline \multicolumn{4}{|l|}{ IL-13 } \\
\hline \multirow[t]{2}{*}{ Unstimulated } & Yes & 0.01 & 0.78 \\
\hline & No & 0.01 & \\
\hline \multirow[t]{2}{*}{ PHA 24 h } & Yes & 508.08 & 0.25 \\
\hline & No & 296.54 & \\
\hline \multirow[t]{2}{*}{ PHA $60 \mathrm{~h}$} & Yes & 1328.16 & $0.02 *$ \\
\hline & No & 1119.87 & \\
\hline \multicolumn{4}{|l|}{ IL-10 } \\
\hline \multirow[t]{2}{*}{ Unstimulated } & Yes & 3.82 & 0.09 \\
\hline & No & 7.96 & \\
\hline \multirow[t]{2}{*}{ PHA 24 h } & Yes & 12.15 & 0.50 \\
\hline & No & 24.25 & \\
\hline \multirow[t]{2}{*}{ PHA $60 \mathrm{~h}$} & Yes & 14.58 & 0.54 \\
\hline & No & 27.60 & \\
\hline
\end{tabular}

$\dagger$ Maternal history of allergic disease was defined as maternal report of one or more of diagnoses of asthma, hay fever, or eczema. For "yes," $n=9$ for "unstimulated" and PHA $60 \mathrm{~h}, n=7$ for PHA $24 \mathrm{~h}$. For "no," $n=17$ for "unstimulated" and PHA $60 \mathrm{~h}, n=13$ for PHA $24 \mathrm{~h}$.

$* p<0.05$ is defined as significant.

activity, lymphocyte proliferation was present, suggesting that cell death or increased proliferation do not explain this finding. In the inactive state, NF- $\kappa \mathrm{B}$ is kept in the cytoplasm via interaction with inhibitory proteins known as $\mathrm{I} \kappa \mathrm{B}$. Activation of NF- $\kappa \mathrm{B}$, in response to a variety of pro-inflammatory signals, leads to the release of the $\mathrm{I} \kappa \mathrm{B}$ subunits from the cytoplasmic complex, which transmigrates into the nucleus, where it activates its target genes upon binding to various $\kappa \mathrm{B}$ motifs (36, 37). Therefore, one possibility is that a decrease of NF- $\kappa \mathrm{B}$ activity in neonates in this study may be due to regulatory mechanisms involving differential activity of the inhibitory factor $I \kappa \mathrm{B}$. Interestingly, in preliminary studies of peripheral blood mononuclear cells of adults and 5-y-old children we have made similar observations (Schaub et al., unpublished data). Although NF- $\kappa \mathrm{B}$ can both enhance and suppress gene transcription, the mechanism of increased and decreased NF- $\kappa \mathrm{B}$ DNA binding activity is the focus of current research $(38,39)$. 
In terms of other transcription factors, we detected mitogeninduced STAT4 and GATA3 binding in cord blood samples. Although STAT4 and GATA3 induce the immune system to skew toward a Th1 or Th2 cytokine pattern, respectively $(6,14$, $15)$, the role of NF- $\kappa \mathrm{B}$ in inducing a distinct cytokine pattern and, in particular, in the early immune system, is not well defined. We and others demonstrated a role for NF- $\kappa \mathrm{B}$ in promoting Th2 cytokine secretion and allergic inflammation using murine models deficient of NF- $\kappa \mathrm{B}$ subunits $(15,26$, $40-42$ ). Although a trend toward increased IL-13 secretion after mitogen stimulation was observed in this study, additional Th 2 cytokines such as IL-5 and IL-10, and also IFN- $\gamma$ secretion (not shown), were not affected by NF- $\kappa$ B activation. Interestingly, NF- $\kappa \mathrm{B}$ activation was decreased when TNF- $\alpha$ secretion at baseline was increased. Elevated TNF- $\alpha$ levels may potentially contribute to subsequent NF- $\kappa \mathrm{B}$ regulation. One explanation may be a negative feedback mechanism of NF- $\kappa \mathrm{B}$ activation by elevated TNF- $\alpha$ secretion; however, the regulation of NF- $\kappa \mathrm{B}$ in nontransformed human cord blood samples may be multifaceted.

$\mathrm{NF}-\kappa \mathrm{B}$ regulation in association with distinct cytokine secretion may contribute to the understanding of immunemediated diseases. A role for NF- $\kappa \mathrm{B}$ in allergic diseases is likely inasmuch as NF- $\kappa \mathrm{B}$ is involved in allergic airway inflammation in murine models $(26,40-43)$ as well as human pulmonary diseases, including asthma $(5,31,44-46)$. NF- $\kappa \mathrm{B}$ is also important in mediating the survival of eosinophils (47), the recruitment of $\mathrm{T}$ lymphocytes to the airways during allergic inflammation $(48,49)$, and the development of $\mathrm{T}$ cells and dendritic cells, critical in allergic disease $(50,51)$. In addition, corticosteroids, a major effective treatment for asthma, are potent blockers of NF- $\kappa \mathrm{B}$ activation.

In this study, NF- $\kappa \mathrm{B}$ regulation was independent of a maternal history of allergic diseases. However, a larger cohort including a higher risk for asthma, or differential stimulation, may indicate a relationship to maternal allergic disease. We observed increased IL-13 and TNF- $\alpha$ secretion after mitogen stimulation in CBMC with a maternal history of allergic disease, the first consistent with a Th2 skewed cytokine pattern observed in the study from Piccinni (52) and our previous work (53). It is possible that in a larger cohort additional cytokines may be associated with a maternal history of allergic disease.

Three features of this cord blood study merit consideration. First, examination of CBMC includes the possibility of maternal contamination $(13,28)$. To address this question, we present a FISH analysis, not previously shown in immunologic assessment of CBMC, and excluded relevant maternal contamination. Second, although mitogen stimulation induces T-cell stimulation and subsequent activation of NF- $\kappa \mathrm{B}$, the precise cell type exhibiting NF- $\kappa$ B activity in this study of CBMC has not been identified. Third, all subjects showed a positive lymphoproliferative response, which is consistent with other reports $(19,22)$. Cord blood lymphocyte proliferation may be a marker for cell viability and functional capacity that is not influenced by NF- $\kappa \mathrm{B}$-induced transcription in this study.

Taken together, our findings demonstrate for the first time that NF- $\kappa \mathrm{B}$ activation is differentially expressed (increased and decreased) in CBMC after mitogen stimulation and that de- creased NF- $\kappa \mathrm{B}$ activity is associated with increased TNF- $\alpha$ secretion. This distinct association may be reflective of yetundefined NF- $\kappa \mathrm{B}$-cytokine pathways in ex vivo samples. Whether the differential regulation of NF- $\kappa \mathrm{B}$ in early life may be associated with the onset of immune-mediated diseases including allergy is under investigation in the longitudinal follow-up study of this cohort.

Acknowledgments. The authors thank the participants and staff of Project Viva, Diane Sredl for program assistance, and Craig Lilly, Fiona Gibbons, and Abdel Bellou for critical review of the manuscript.

\section{REFERENCES}

1. Marquardt DL, Walker LL 2000 Dependence of mast cell IgE-mediated cytokine production on nuclear factor-kappaB activity. J Allergy Clin Immunol 105:500-505

2. Schmedtje Jr JF, Ji YS, Liu WL, DuBois RN, Runge MS 1997 Hypoxia induces cyclooxygenase-2 via the NF-kappaB p65 transcription factor in human vascular endothelial cells. J Biol Chem 272:601-608

3. Chu SC, Marks-Konczalik J, Wu HP, Banks TC, Moss J 1998 Analysis of the cytokine-stimulated human inducible nitric oxide synthase (iNOS) gene: characterization of differences between human and mouse iNOS promoters. Biochem Biophys Res Commun 248:871-878

4. Escoubet-Lozach L, Glass CK, Wasserman SI 2002 The role of transcription factors in allergic inflammation. J Allergy Clin Immunol 110:553-564

5. Christman JW, Sadikot RT, Blackwell TS 2000 The role of nuclear factor-kappa B in pulmonary diseases. Chest 117:1482-1487

6. Barnes PJ, Karin M 1997 Nuclear factor-kappaB: a pivotal transcription factor in chronic inflammatory diseases. N Engl J Med 336:1066-1071

7. Christman JW, Lancaster LH, Blackwell TS 1998 Nuclear factor kappa B: a pivotal role in the systemic inflammatory response syndrome and new target for therapy. Intensive Care Med 24:1131-1138

8. Bureau F, Delhalle S, Bonizzi G, Fievez L, Dogne S, Kirschvink N, Vanderplasschen A, Merville MP, Bours V, Lekeux P 2000 Mechanisms of persistent NF-kappaB activity in the bronchi of an animal model of asthma. J Immunol 165:5822-5830

9. Baeuerle PA, Baltimore D 1996 NF-kappa B: ten years after. Cell 87:13-20

10. Baldwin Jr AS 2001 Series introduction: the transcription factor NF-kappaB and human disease. J Clin Invest 107:3-6

11. Siebenlist U, Franzoso G, Brown K 1994 Structure, regulation and function of NF-kappa B. Annu Rev Cell Biol 10:405-455

12. Prescott SL 2001 The significance of immune responses to allergens in early life. Clin Exp Allergy 31:1167-1169

13. Prescott SL, Macaubas C, Holt BJ, Smallacombe TB, Loh R, Sly PD, Holt PG 1998 Transplacental priming of the human immune system to environmental allergens: universal skewing of initial $\mathrm{T}$ cell responses toward the $\mathrm{Th} 2$ cytokine profile. J Immunol 160:4730-4737

14. Macaubas C, Holt PG 2001 Regulation of cytokine production in T-cell responses to inhalant allergen: GATA-3 expression distinguishes between Th1- and Th2-polarized immunity. Int Arch Allergy Immunol 124:176-179

15. Das J, Chen CH, Yang L, Cohn L, Ray P, Ray A 2001 A critical role for NF-kappa $\mathrm{B}$ in GATA3 expression and $\mathrm{TH} 2$ differentiation in allergic airway inflammation. Nat Immunol 2:45-50

16. Warner JA, Miles EA, Jones AC, Quint DJ, Colwell BM, Warner JO 1994 Is deficiency of interferon gamma production by allergen triggered cord blood cells a predictor of atopic eczema? Clin Exp Allergy 24:423-430

17. Rinas U, Horneff G, Wahn V 1993 Interferon-gamma production by cord-blood mononuclear cells is reduced in newborns with a family history of atopic disease and is independent from cord blood IgE-levels. Pediatr Allergy Immunol 4:60-64

18. Liao SY, Liao TN, Chiang BL, Huang MS, Chen CC, Chou CC, Hsieh KH 1996 Decreased production of IFN gamma and increased production of IL- 6 by cord blood mononuclear cells of newborns with a high risk of allergy. Clin Exp Allergy 26:397-405

19. Jones AC, Miles EA, Warner JO, Colwell BM, Bryant TN, Warner JA 1996 Fetal peripheral blood mononuclear cell proliferative responses to mitogenic and allergenic stimuli during gestation. Pediatr Allergy Immunol 7:109-116

20. Szepfalusi Z, Nentwich I, Gerstmayr M, Jost E, Todoran L, Gratzl R, Herkner K, Urbanek R 1997 Prenatal allergen contact with milk proteins. Clin Exp Allergy 27:28-35

21. Chan-Yeung M, Ferguson A, Chan H, Dimich-Ward H, Watson W, Manfreda J, Becker A 1999 Umbilical cord blood mononuclear cell proliferative response to house dust mite does not predict the development of allergic rhinitis and asthma. J Allergy Clin Immunol 104:317-321

22. Smillie FI, Elderfield AJ, Patel F, Cain G, Tavenier G, Brutsche M, Craven M, Custovic A, Woodcock A 2001 Lymphoproliferative responses in cord blood and at one year: no evidence for the effect of in utero exposure to dust mite allergens. Clin Exp Allergy 31:1194-1204

23. Miller RL, Chew GL, Bell CA, Biedermann SA, Aggarwal M, Kinney PL, Tsai WY, Whyatt RM, Perera FP, Ford JG 2001 Prenatal exposure, maternal sensitization, and 
sensitization in utero to indoor allergens in an inner-city cohort. Am J Respir Crit Care Med 164:995-1001

24. Prescott SL, Holt PG 1998 Abnormalities in cord blood mononuclear cytokine production as a predictor of later atopic disease in childhood. Clin Exp Allergy 28:1313-1316

25. Schreiber E, Matthias P, Muller MM, Schaffner W 1989 Rapid detection of octamer binding proteins with 'mini-extracts', prepared from a small number of cells. Nucleic Acids Res 17:6419

26. Donovan CE, Mark DA, He HZ, Liou HC, Kobzik L, Wang Y, De Sanctis GT, Perkins DL, Finn PW 1999 NF-kappa B/Rel transcription factors: c-Rel promotes airway hyperresponsiveness and allergic pulmonary inflammation. $\mathrm{J}$ Immunol 163:6827-6833

27. Finn PW, Stone JR, Boothby MR, Perkins DL 2001 Inhibition of NF-kappaBdependent $\mathrm{T}$ cell activation abrogates acute allograft rejection. J Immunol 167:59946001

28. Clerici M, DePalma L, Roilides E, Baker R, Shearer GM 1993 Analysis of T helper and antigen-presenting cell functions in cord blood and peripheral blood leukocytes from healthy children of different ages. J Clin Invest 91:2829-2836

29. Szepfalusi Z, Pichler J, Elsasser S, van Duren K, Ebner C, Bernaschek G, Urbanek R 2000 Transplacental priming of the human immune system with environmental allergens can occur early in gestation. J Allergy Clin Immunol 106:530-536

30. Holt PG, O'Keeffe P, Holt BJ, Upham JW, Baron-Hay MJ, Suphioglu C, Knox B, Stewart GA, Thomas WR, Sly PD 1995 T-cell "priming" against environmental allergens in human neonates: sequential deletion of food antigen reactivity during infancy with concomitant expansion of responses to ubiquitous inhalant allergens. Pediatr Allergy Immunol 6:85-90

31. Hart LA, Krishnan VL, Adcock IM, Barnes PJ, Chung KF 1998 Activation and localization of transcription factor, nuclear factor-kappaB, in asthma. Am J Respir Crit Care Med 158:1585-1592

32. Jarvis JN, Zhao L, Xu CS, Moore HT, Berry S 1997 Constitutive expression c-fos, c-jun, and NF kappa B mRNA is in nucleated fetal blood cells and up-regulation of c-fos and c-jun with anti-CD3 stimulation. Biol Neonate 72:329-336

33. Vancurova I, Bellani P, Davidson D 2001 Activation of nuclear factor-kappaB and its suppression by dexamethasone in polymorphonuclear leukocytes: newborn versus adult. Pediatr Res 49:257-262

34. Kilpinen S, Henttinen T, Lahdenpohja N, Hulkkonen J, Hurme M 1996 Signals leading to the activation of NF-kappa B transcription factor are stronger in neonatal than adult T lymphocytes. Scand J Immunol 44:85-88

35. Vancurova I, Miskolci V, Davidson D 2001 NF-kappa B activation in tumor necrosis factor alpha-stimulated neutrophils is mediated by protein kinase Cdelta. Correlation to nuclear Ikappa Balpha. J Biol Chem 276:19746-19752

36. Akira S, Kishimoto T 1997 NF-IL6 and NF-kappa B in cytokine gene regulation. Adv Immunol 65:1-46

37. Baldwin Jr AS 1996 The NF-kappa B and I kappa B proteins: new discoveries and insights. Annu Rev Immunol 14:649-683

38. Muller CW, Rey FA, Harrison SC 1996 Comparison of two different DNA-binding modes of the NF-kappa B p50 homodimer. Nat Struct Biol 3:224-227
39. Picado C, Bioque G, Roca-Ferrer J, Pujols L, Mullol J, Benitez P, Bulbena O 2003 Nuclear factor-kB activity is down-regulated in nasal polyps from aspirin-sensitive asthmatics. Allergy 58:122-126

40. Aronica MA, Mora AL, Mitchell DB, Finn PW, Johnson JE, Sheller JR, Boothby MR 1999 Preferential role for NF-kappa B/Rel signaling in the type 1 but not type $2 \mathrm{~T}$ cell-dependent immune response in vivo. J Immunol 163:5116-5124

41. Lin C-C, Lin C-Y, Ma H-Y 2000 Pulmonary function changes and increased Th-2 cytokine expression and nuclear factor $\mathrm{kB}$ activation in the lung after sensitization and allergen challenge in brown Norway rats. Immunol Lett 73:57-64

42. Yang L, Cohn L, Zhang DH, Homer R, Ray A, Ray P 1998 Essential role of nuclear factor kappaB in the induction of eosinophilia in allergic airway inflammation. J Exp Med 188:1739-1750

43. Liu SF, Haddad EB, Adcock I, Salmon M, Koto H, Gilbey T, Barnes PJ, Chung KF 1997 Inducible nitric oxide synthase after sensitization and allergen challenge of Brown Norway rat lung. Br J Pharmacol 121:1241-1246

44. Stacey MA, Sun G, Vassalli G, Marini M, Bellini A, Mattoli S 1997 The allergen Der p1 induces NF-kappaB activation through interference with IkappaB alpha function in asthmatic bronchial epithelial cells. Biochem Biophys Res Commun 236:522-526

45. Di Stefano A, Caramori G, Oates T, Capelli A, Lusuardi M, Gnemmi I, Ioli F, Chung KF, Donner CF, Barnes PJ, Adcock IM 2002 Increased expression of nuclear factor-kappaB in bronchial biopsies from smokers and patients with COPD. Eur Respir J 20:556-563

46. Graziano FM, Cook EB, Stahl JL 1999 Cytokines, chemokines, RANTES, and eotaxin. Allergy Asthma Proc 20:141-146

47. Hoontrakoon R, Chu HW, Gardai SJ, Wenzel SE, McDonald P, Fadok VA, Henson PM, Bratton DL 2002 Interleukin-15 inhibits spontaneous apoptosis in human eosinophils via autocrine production of granulocyte macrophage-colony stimulating factor and nuclear factor-kappa B activation. Am J Respir Cell Mol Biol 26:404-412

48. Hidi R, Riches V, Al-Ali M, Cruikshank WW, Center DM, Holgate ST, Djukanovic R 2000 Role of B7-CD28/CTLA-4 costimulation and NF-kappa B in allergen-induced T cell chemotaxis by IL-16 and RANTES. J Immunol 164:412-418

49. Kawano T, Matsuse H, Kondo Y, Machida I, Saeki S, Tomari S, Mitsuta K, Obase Y, Fukushima C, Shimoda T, Kohno S 2003 Cysteinyl leukotrienes induce nuclear factor kappa $\mathrm{b}$ activation and RANTES production in a murine model of asthma. J Allergy Clin Immunol 112:369-374

50. Boffa DJ, Feng B, Sharma V, Dematteo R, Miller G, Suthanthiran M, Nunez R, Liou HC 2003 Selective loss of c-Rel compromises dendritic cell activation of T lymphocytes. Cell Immunol 222:105-115

51. Barton D, HogenEsch H, Weih F 2000 Mice lacking the transcription factor RelB develop $T$ cell-dependent skin lesions similar to human atopic dermatitis. Eur J Immunol 30:2323-2332

52. Piccinni MP, Beloni L, Giannarini L, Livi C, Scarselli G, Romagnani S, Maggi E 1996 Abnormal production of T helper 2 cytokines interleukin- 4 and interleukin- 5 by T cells from newborns with atopic parents. Eur J Immunol 26:2293-2298

53. Contreras JP, Ly NP, Gold DR, He H, Wand M, Weiss ST, Perkins DL, Platts-Mills TA, Finn PW 2003 Allergen-induced cytokine production, atopic disease, IgE, and wheeze in children. J Allergy Clin Immunol 112:1072-1077 